\title{
TAKING HUMAN RIGHTS NOT TOO SERIOUSLY
}

\begin{abstract}
The doctrine of human rights is undergoing a difficult test today. On the one hand, we are dealing with a recurring question about its universality. Is it only an expression of Western anthropological sensitivity and should therefore be observed only in the West, or does it refer to human nature as it is and should therefore be observed everywhere, including in Islamic civilisation? On the other hand, secularisation detaches the doctrine from its theistic sources, resulting in its positivisation. Human rights in this version would only be the result of agreements between people and, therefore, like any other social contract, could be freely changed or reinterpreted. An example of such a reinterpretation of the doctrine is the proposal to recognise abortion as a human right. The author also addresses these issues from the position of Catholic social teaching and raises the question of the consequences of these changes for the Church and its official absolute or conditional support for the doctrine.
\end{abstract}

Keywords: human dignity, human rights, anthropology, secularisation, ideology, Catholic Church. 
A narrow humanism, closed in on itself and not open to the values of the spirit and to God who is their source, could achieve apparent success, for man can set about organizing terrestrial realities without God. But "closed off from God, they will end up being directed against man. A humanism closed off from other realities becomes inhuman" (Paul VI). ${ }^{1}$

It is evident (...) that the rights recognized and expounded in the Declaration apply to everyone by virtue of the common origin of the person, who remains the high-point of God's creative design for the world and for history. They are based on the natural law inscribed on human hearts and present in different cultures and civilizations. Removing human rights from this context would mean restricting their range and yielding to a relativistic conception, according to which the meaning and interpretation of rights could vary and their universality would be denied in the name of different cultural, political, social and even religious outlooks. This great variety of viewpoints must not be allowed to obscure the fact that not only rights are universal, but so too is the human person, the subject of those rights (Benedict XVI). ${ }^{2}$

\section{THE DRAMA OF LEGAL POSITIVISM}

In his address to the Bundestag, Benedict XVI said that European culture is in a dramatic situation that urgently requires public discussion. It's about the drama of legal positivism. "Where positivist reason dominates the field to the exclusion of all else - and that is broadly the case in our public mindset - then the classical sources of knowledge for ethics and law are excluded." ${ }^{3}$ The situation is dramatic because "(...) where positivist reason considers itself the only sufficient culture and banishes all other cultural realities to the status of subcultures, it diminishes man, indeed it threatens his humanity."

\footnotetext{
1 Paul VI, Populorum progressio, 42, http://w2.vatican.va/content/paul-vi/en/ encyclicals/documents/hf_p-vi_enc_26031967_populorum.html [access: August 28, 2018].

2 Benedict XVI, Address to the General Assembly of the United Nations Organization, April 18, 2008, http://w2.vatican.va/content/benedict-xvi/en/speeches/2008/april/ documents/hf_ben-xvi_spe_20080418_un-visit.html [access: August 28, 2018].

3 Benedict XVI, Address to the Bundestag, September 22, 2011, http://w2.vatican.va/ content/benedict-xvi/en/speeches/2011/september/documents/hf_ben-xvi_spe_20110922_ reichstag-berlin.html [access: August 28, 2018].

4 Ibidem.
} 
It is not by coincidence that Pope Benedict put the question concerning positivism in the German parliament. Recalling the words of Saint Augustine on the countries deprived of justice, which are changed into "the big bands of robbers" (De civitate Dei, IV, 4, 1), the Holy Father states: "We Germans know from our own experience that these words are no empty specter. We have seen how power became divorced from right, how power opposed right and crushed it, so that the State became an instrument for destroying right - a highly organized band of robbers, capable of threatening the whole world and driving it to the edge of the abyss." It seems that only asking the question about positivism in the context of the risk of repeating such radical consequences is treating this matter with due seriousness.

St. Augustine view inspired the reflection, among others, of Hans Kelsen. He states that the difference between the state and the band is not based on the lack of any order. After all, in each band some rules must apply. "If robbery and murder were not forbidden in the relations between the robbers, no community, no robber gang would exist." 6 According to Kelsen, such a criterion is the effectiveness of the coercive order. "If the validity of this coercive order is restricted to a certain territory and of it is effective within this territory in such a way that the validity of any other coercive order of this kind is excluded, then the coercive order may indeed be regarded as a legal order and the community constituted by it may be regarded as a 'state' - even if its external activity is illegal according to positive international law." The only thing that matters is whether this state guarantees "the minimum of collective security (...) which is the condition for the existence of a relatively lasting community constituted by a normative order." ${ }^{8}$ The way that Kelsen excludes justice as a criterion differentiating the state and band of brigands is somewhat more complicated. It refers to the general principle of the separation of law and morality. "The demand for a separation between law and morals, law and justice, means that validity of a positive legal order is independent of the validity of this one, solely valid, absolute moral order, 'the' moral order, the moral order par excellence." That's because legal positivism is in principle related to axiological relativism. It is not synonymous with the belief that values do not exist at all, but "that the values as established by our

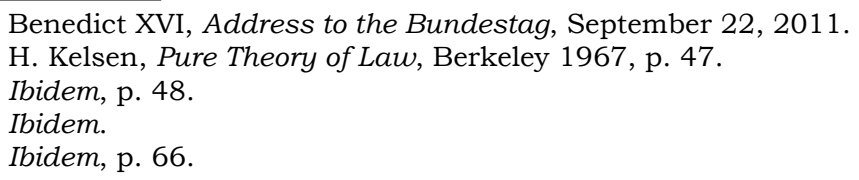


norm-creating acts cannot claim to exclude the possibility of opposite values." ${ }^{10}$ If - according to Saint Augustine suggestion - one would accept justice as a criterion distinguishing the state from the gang of the robbers, it would have to be absolute justice, and - from the point of view of positivism - this is unacceptable. However, even if justice would be understood in a relativistic way, the logical consequences of recognizing it as a decisive criterion will be unacceptable. "If justice is assumed to be the criterion for a normative order to be designated as 'law', then the capitalist coercive order of the West is not law from the point of view of the Communist ideal of justice, nor the Communist coercive order of the Soviet Union from the point of view of the capitalist ideal of justice. A concept of law with such consequences is unacceptable by a positivist legal science." ${ }^{11}$ Although Western countries did have some difficulties in recognizing the communist coercive order as a legal order, but, as Kelsen observes, the "triumph" of positivism was to overcome these fears at a time when revolution-born order turned out to be permanently effective. ${ }^{12}$ In other words, the category of states - bands of robbers is empty. Although liberalism speaks today about "failed states," but the term primarily means states that are unable to control the whole situation on the territory. It does not refer to the category of justice, but to sovereignty.

Gustav Radbruch also deals with the term "criminal state" in a text published in 1946 entitled Statutory lawlessness and over statutory law. "National socialism, writes Radbruch, managed to convince on one side the cortege of soldiers and, on the other, the group of jurists, using two elementary principles: 'order means order' and 'law means law'." ${ }^{13}$ There is no reason to be surprised by the soldiers, although also in their case the duty of obedience ceases as soon as it turns out that the order was given in criminal intent or with the abuse of law. Lawyers, however, should be more intelligent. Meanwhile, it was they who disarmed the system and made society totally defenseless against the approaching totalitarianism: "It is the understanding of law and its validity, called positivism, writes Radbruch, that contributed to the fact that both lawyers and the ordinary people have become completely defenseless against arbitrary, inhuman and criminal laws. This theory ultimately placed a sign of equality between law and force: where is

\footnotetext{
10 H. Kelsen, Pure Theory of Law, p. 67.

Ibidem, p. 49.

Cf. ibidem, p. 50.

13 G. Radbruch, Philosophy of Law (Polish edition: Filozofia prawa, Wydawnictwo Naukowe PWN, Warszawa 2011), p. 244.
} 
the power, there is the law. (...) identifying the right with an alleged or expected social benefit has made the state of law a lawless state." ${ }^{14}$ In a Five-minute lecture on philosophy of law, Radbruch states that the purpose of law is not just to establish justice, but also to care for mutual benefit and legal security. Because man is a defective being, it is not always possible to harmonize these goals with one another. Hence, a certain lack of justice must be tolerated. "Lawyers and citizens in their minds must be deeply aware of the fact that laws are possible that go through any measure of social injustice and harmfulness, laws that must be denied not only the binding force, but also any legal character." 15

Being aware that legal positivism contributed in a significant way to the almost complete disappearance of resistance to Nazism, Benedict XVI cites in the Bundestag a remark made already in the third century by Origen. Origen, justifying the resistance of Christians to some Roman legal norms, stated that a man who would one day be under the rule of Scythian wicked laws (the laws of the devil) would have the moral duty not only to refuse to submit to them but also to plot to overthrow those rights and replace them with decent ones. ${ }^{16}$ So, what should the Germans (or at least German Catholics) do in Nazi times? The pope's answer is simple - they should plot. "This conviction - says Benedict - was what motivated resistance movements to act against the Nazi regime and other totalitarian regimes, thereby doing a great service to justice and to humanity as a whole. For these people, it was indisputably evident that the law in force was actually unlawful." ${ }^{17}$ The plot was then the only moral action.

The conclusions from the above deliberations may seem trivial. On the one hand, from the point of view of positivism, there is no necessary relationship between law and morality. On the other hand, the fact that positivism understood in this way leads to recognition as legal also of activities which exceed all measure of injustice. Why, however, did Benedict XVI decide to comment on this issue in the parliament? Provided justification is of a dual nature. First of all, the point is that the tools that are at the disposal of man today - if they were misused - are able to cause unimaginably greater damage than

${ }^{14}$ G. Radbruch, Philosophy of Law, p. 241-242.

15 Ibidem, p. 243.

16 Cf. Origen, Contra Celsum, I,1, http://www.documentacatholicaomnia.eu/03d/ 0185-0254,_Origenes,_Contra_Celsus,_EN.pdf [access: August 28, 2018].

17 Benedict XVI, Address to the Bundestag, http://w2.vatican.va/content/benedictxvi/en/speeches/2011/september/documents/hf_ben-xvi_spe_20110922_reichstag-berlin. html [access: August 28, 2018]. 
those available to criminals at the time of the Second World War. "To serve right and to fight against the dominion of wrong - says the Pope - is and remains the fundamental task of the politician. At a moment in history when man has acquired previously inconceivable power, this task takes on a particular urgency. Man can destroy the world. He can manipulate himself. He can, so to speak, make human beings and he can deny them their humanity." 18 Secondly, in the context of decisions made by the will of the majority, we are today more vulnerable to the risk of the state transforming itself into "statutory lawlessness." The evidence of this lawlessness in the situation of maintaining the formal rules of democracy, even if it was only a totalitarian democracy - as Jakob Talmon calls it - is not obvious. ${ }^{19}$ "For most of the matters that need to be regulated by law, the support of the majority can serve as a sufficient criterion. Yet it is evident that for the fundamental issues of law, in which the dignity of man and of humanity is at stake, the majority principle is not enough: everyone in a position of responsibility must personally seek out the criteria to be followed when framing laws. (...) The question of how to recognize what is truly right and thus to serve justice when framing laws has never been simple, and today in view of the vast extent of our knowledge and our capacity, it has become still harder." ${ }^{20}$ It seemed that this issue, due to the reference to natural law, especially after the Second World War, was finally clarified, but these hopes were vain. "If this seemed to offer a clear explanation of the foundations of legislation up to the time of the Enlightenment, up to the time of the Declaration on Human Rights after the Second World War and the framing of our Basic Law - Benedict XVI writes - there has been a dramatic shift in the situation in the last half-century. The idea of natural law is today viewed as a specifically Catholic doctrine, not worth bringing into the discussion in a non-Catholic environment, so that one feels almost ashamed even to mention the term." ${ }^{21}$ We have, therefore, the problem of tools that can be used to destroy human dignity, difficulties with the democratic justification of the dignity, and everything happens in the context of culture, in which the theory

18 Benedict XVI, Address to the Bundestag.

19 Cf. J.L. Talmon, The Origins of Totalitarian Democracy, London 1952. Recently this topic was discussed by Chantal Delsol, Leszek Kołakowski, Timothy Snyder, Robert Spaemann, and others.

20 Benedict XVI, Address to the Bundestag.

21 Ibidem. 
of natural law, which was the basic ground to justify the inviolability of this dignity, has become an object of mockery.

\section{BARSABBAS' TIME 22}

The text of the Universal Declaration of Human Rights shows that the circumstance definitely facilitating its adoption was a shock in the face of "barbarous acts which have outraged the conscience of mankind" (UDHR, Preambel). In other words, the sentences written by Radbruch saying that "the laws on the forfeiture of Jewish property to the state were contrary to natural law and already at the moment of creation had no validity" ${ }^{3}$ or the conviction that: "The nature of law are devoid (...) all the laws without exception, addressed to the category of alleged 'subhumans' and denying human rights to the latter," ${ }^{4}$ were perfectly understandable (self-evident as declared by the United States Declaration of Independence) and did not require additional justification. It was also evident that "in order to protect against the recurrence of the state of lawlessness, one must ... totally overcome positivism, because it is positivism which deprives any law of all resistance to the legislative abuse of national socialism." ${ }^{25}$ With time, as the acts of barbarism were blurred in the memory, what was obvious has ceased to be so evident. Probably the temporal distance in relation to totalitarian system is also the cause of a somewhat different sensitivity to human rights in countries that have just emerged from communism and those for whom the last totalitarian experience was German Nazism.

The concept of natural human rights is currently challenged with at least three different positions. According to Vittorio Possenti, the first argument against it is the accusation of Occidentalism. ${ }^{26}$ Human rights would be a Western product imposed on the rest of the world as part of cultural imperialism hostile to any diversity. The discourse exposes such categories of thought as the Western concept of law, Western anthropology or individualism. Meanwhile, Asian or African

22 The phrase was used by Felice Balbo to describe the phenomenon of "deification of immanence" (see: F. Balbo, Opere 1945-1964, Torino 1966, p. 193, after: V. Possenti, Diritti umani. L'età delle pretese, Rubbettino, Soveria Mannelli 2017, p. 77).

${ }_{23}$ Decision of the District Court in Wiesbaden, after: G. Radbruch, Philosophy of Law, p. 244.

${ }^{24}$ G. Radbruch, Philosophy of Law, p. 251.

25 Ibidem.

${ }^{26}$ Cf. V. Possenti, Diritti umani. L'età delle pretese, p. 42-43. 
cultures have their own legal traditions within which the categories of duty, community and authority play a much greater role. Submitting to Western pressure would be tantamount to giving up their own cultural identity. Western world hypocrisy is giving an additional color to this controversy. The West, on the one hand intensely defends universal human rights, and on the other hand remains completely indifferent to the evident violation of these laws by Westerners against the inhabitants of poor countries, especially in such areas as sex tourism, production of pornography, surrogacy or trade in human organs. ${ }^{27}$ The polemical tone towards the Western vision of human rights is clearly heard in the Declaration of Bangkok (1993). While Asian ministers recognize the universality, objectivity and inseparability of human rights, they also emphasize their historical, cultural and religious conditioning. ${ }^{28}$

Another argument questioning the universality of human rights is used by Islam. The point of criticism is directed not so much against the rights themselves as against their autonomous character. Human rights and duties come from God. They do not belong to man because of being human, but due to be a follower of Islam. "Islam gave to mankind an ideal code of human rights fourteen centuries ago - reads in the preamble of the Universal Declaration of Islamic Human Rights of 1981 - These rights aim at conferring honour and dignity on mankind and eliminating exploitation, oppression and injustice. Human rights in Islam are firmly rooted in the belief that God, and God alone, is the Law Giver and the Source of all human rights. Due to their Divine origin, no ruler, government, assembly or authority can curtail or violate in any way the human rights conferred by God, nor can they be surrendered. Human rights in Islam are an integral part of the overall Islamic order and it is obligatory on all Muslim governments and organs of society to implement them in letter and in spirit within the framework of that order." 29 The religious nature of these rights is

${ }^{27}$ Cf. R. Sarah, N. Diat, Le soir approche et déjà le jour baisse, Paris 2019, p. 216-219.

28 "Recognize that while human rights are universal in nature, they must be considered in the context of a dynamic and evolving process of international norm-setting, bearing in mind the significance of national and regional particularities and various historical, cultural and religious backgrounds" (Final Declaration of the Regional Meeting for Asia of the World Conference on Human Rights, April 02, 1993, n. 8, faculty.washington.edu/.../pols469/ Bangkok_Declaration.doc [access: July 08, 2019]). See also: B.S.B. Chan, Are International Human Rights Universal? East-West Philosophical Debates on Human Rights to Liberty and Health, in: L.Di Donato, E. Grimi (eds), Metaphysics of Human Rights.1948-2018. On the Occasion of the 70th Anniversary of the UDHR, Malaga 2018, p. 110-120.

29 Universal Islamic Declaration of Human Rights, Foreword, http://www.alhewar. com/ISLAMDECL.html [access: August 28, 2018]. 
also highlighted in the preamble of the Declaration of Human Rights in Islam drafted by the Islamic Conference Organization on August 5, 1990, where we find the following motto: "Believing that fundamental rights and freedoms according to Islam are an integral part of the Islamic religion and that no one shall have the right as a matter of principle to abolish them either in whole or in part or to violate or ignore them in as much as they are binding divine commands, which are contained in the Revealed Books of Allah and which were sent through the last of His Prophets to complete the preceding divine messages and that safeguarding those fundamental rights and freedoms is an act of worship whereas the neglect or violation thereof is an abominable sin, and that the safeguarding of those fundamental rights and freedom is an individual responsibility of every person and a collective responsibility of the entire Ummah." ${ }^{30}$ The link between human rights and Islam is seen here as something obvious, because "Islam is the religion of unspoiled nature" (Article 10). The consequence of this fact is the recognition of the law of sharia as the overarching interpretative framework within which an individual benefit from his human rights. A good example of such an interpretation of human rights is art. 12 of the Declaration: "Every man shall have the right, within the framework of Shari'ah, to free movement and to select his place of residence whether inside or outside his country and, if persecuted, is entitled to seek asylum in another country."

The third type of undermining the universality of human rights we encounter in the Western world. Possenti shows three Western strategies for the relativisation of human rights. The first is connected with their positivization, the second - with the constant extension of the concept of human rights through the so-called new rights, the third - with the internationalization of human rights. ${ }^{31}$ The classic theory of human rights was developed on the basis of natural law, putting in the center the inherent, inalienable and inviolable dignity of the human person. Placing human rights in a post-metaphysical context removes this common ground. The consequence is the widely held conviction that the validity of human rights cannot be justified, because they are the fruit of a historical consensus, which - like everything historical - is changing; however, human rights

${ }^{30}$ Cairo Declaration on Human Rights in Islam, Preamble, http://www.bahaistudies. net/neurelitism/library/Cairo_Declaration_on_Human_Rights_in_Islam.pdf [access: August $28,2018]$.

31 Cf. V. Possenti, Diritti umani. L'età delle pretese, p. 22. 
can and should be protected. ${ }^{32}$ Though, this is not a philosophical problem but a political one. The detailed philosophical assumptions underlying this "anti-philosophical" attitude can be of at least two kinds. In the first type, the existence of the subject of these rights is rejected, and therefore the conviction that there is a man endowed with an unchanging species nature. In the second, as the source of these rights is acknowledged not the nature of man, but or his subjective individual conscience or the social contract. The reasons for recognizing specific human rights are only pragmatic or emotional (benefit, interest, power). Specific human rights are recognized as binding prima facie and then reinforced by social consensus or by entering into international law documents. However, these are not absolute rights. Because there were established by the legislator will expressed in a document of positive law (declaration, convention, charter, constitution) (Potestas, non-veritas facit legem), their scope can be broadened, and their interpretation is subject to change. ${ }^{33}$ Instead of talking about absolute rights, it seems more correct to speak about absolute power (legislative or judicial) which - in its own meaning - does not recognize other limitations of its competences than those which result from the need to maintain certain procedures.

Positivization of human rights relates to granting not so much primacy, but almost exclusive rights to procedural logic. Human rights are transformed into a somewhat more "universal" version of citizens' rights, emerging as a result of public recognition of "civic dignity" or "global citizenship." The second important element of positivization is the mentioned negation of natural law and unchanging human nature. Here comes the old problem posed by David Hume, concerning the possibility of passing from facts to duties, from "is" to "should." 34 Human nature is captured here in a biological way, not philosophical (ontological) one. The similarity of man to animals is considered more important from the point of view of his identity than his non-likeness. What is considered natural for a human being - and what should be protected by human rights - is not determined by its rationality but by physiology.

${ }^{32}$ Cf. V. Possenti, Diritti umani. L'età delle pretese, p. 26.

${ }^{33}$ Cf. Ibidem, p. 40.

${ }_{34}$ Cf. D. Hume, A Treatise of Human Nature, I.I.1, iBooks. https://itunes.apple.com/ pl/book/a-treatise-of-human-nature/id506006779?l=pl\&mt=11; Alasdair MacIntyre showed convincingly that Hume's way of thinking is wrong (Cf. A. MacIntyre, After virtue. A Study in Moral Theory (Polish edition: A. MacIntyre, Dziedzictwo cnoty. Studium z teorii moralności, Wydawnictwo Naukowe PWN, Warszawa 1996) V, p. 117-123. 
The enlargement of the scope of human rights is closely related to their positivization. Since human rights are nor "recognized" but "produced" by the community, as the social context changes, it is possible to add new laws and reinterpret the rights previously recognized. There are no pre-determined limits in the process of adding and reinterpreting. According to Marcelo Pera, the unrestricted proliferation of human rights (proliferazione illimitata dei diritti umani) is not some accidental result of the evolution of doctrine but is inscribed in the very logic of the human rights system, according to which rights generate further rights. ${ }^{35}$ The areas in which the most of "new rights" appear today are human sexuality, biopolitics and non-discrimination policies. On the field of human sexuality, it is a gender ideology that does not recognize the natural sex difference and the different role of each of the two sexes in the conception and birth of a child. Therefore, there is a belief in the existence of a human right to freely choose the sex, an attempt to redefine the institution of marriage and family or the concept of "social infertility" and the individual right to have a child which could be enforced on the state. In the case of biopolitics, it is about perceiving life on the likeness of an unshaped "rough material" which only when it takes a form can be regarded as "something." Sometimes people say about "naked life," which only through a certain technological processing will become the life of a concrete being. At this first stage, there would be no moral restrictions, even if it is human life which is subjected to the technological processing. In this context, discussion about experiments on human embryonic stem cells, on the creation of human chimeras and hybrids, in vitro fertilization, surrogacy, children made "on request," "human enhancement," abortion or eugenics should be perceived. It seems that we are dealing here with the process of evaluating human life, under which the lives of certain people are considered "unworthy of life." This logic is particularly easy to grasp in the case of selection of human embryos before implementation under the in vitro procedure, abortion due to the suspicion of disability or illness, or euthanasia due to age-related dementia. Such practices also take place in Europe, despite the Convention on Human Rights and Biomedicine (1997) and the Charter of Fundamental Rights of the EU, which in art. 3 par. $2 \mathrm{~b}$ expressly prohibits 'eugenic practices, in particular those aiming at the selection of persons'. Also, the

${ }^{3}$ Cf. M. Pera, Diritti umani e cristianesimo. La Chiesa alla prova della modernità, Venezia 2015, p. 51. 
policy of non-discrimination detached from European anthropological traditions leads to the articulation of "new laws," sometimes at odds with the natural law.

\section{IDEOLOGICAL COLONIZATION IN THE NAME OF HUMAN RIGHTS}

Many of human rights are not just a simple emanation of natural law, but the effect of more detailed specification of these laws in the course of history in fidelity to their sources. Better awareness of the content of specific rights was usually gained in the context of their open violation. ${ }^{36}$ Human rights are subject to some kind of evolution also in the context of natural law (within the third level of natural law), but only in the sense that we improve their understanding and are able to detail them better in new contexts. The result is that not all new initiatives should be thrown into the same basket. ${ }^{37}$ Some of them have a deep sense, such as attempts to ban the use of anti-personnel mines or act against new forms of exploitation of children in the labor market. Others, referring to the postmodern anthropology, are in clear conflict with the "old laws," an example of which is the so-called the right to have a child (regardless of whether it is a heterosexual or homosexual couple or a single person), the right to anonymity of biological parents in an in vitro procedure, conflicting with the right of the child to have a father and mother and the right of the child to know his/her parents and stay in their care. ${ }^{38}$ The process of clarifying human rights makes sense to us as long as we remain on the ground of natural law and the correct concept of the person which sets the limits of acceptable changes. ${ }^{39}$

Speaking to the Diplomatic Corps at the Vatican, Pope Francis said: "Those [human] rights are premised on the nature objectively shared by the human race. They were proclaimed in order to remove the barriers that divide the human family and to favor what the Church's social doctrine calls integral human development, since it entails fostering the development of each man and of the whole man... and

\footnotetext{
${ }^{36}$ Cf. V. Possenti, Diritti umani. L'età delle pretese, p. 35.

${ }_{37}$ The boundary line seems to run between rights "recognized" by the state, and rights "created" by the state.

${ }^{38} \mathrm{Cf}$. Convention on the Rights of the Child, 7, https://www.ohchr.org/en/ professionalinterest/pages/crc.aspx [access: August 28, 2018].

${ }_{39} \mathrm{Cf}$. V. Possenti, Diritti umani. L'età delle pretese, p. 35.
} 
humanity as a whole'. (...) It should be noted, however, that over the years, particularly in the wake of the social upheaval of the 1960's, the interpretation of some rights has progressively changed, with the inclusion of a number of 'new rights' that not infrequently conflict with one another." 40 Suggesting new, highly controversial issues (e.g. the so-called right to abortion or legal recognition of unions of people of the same sex) and attempts by some Western countries to force their integration into the legal systems of developing countries, despite the explicit contradiction of these demands with the socio-cultural traditions of these countries, often increases tensions in international relations. "Somewhat paradoxically, there is a risk that, in the very name of human rights, we will see the rise of modern forms of ideological colonization by the stronger and the wealthier - says Francis - to the detriment of the poorer and the most vulnerable. At the same time, it should be recalled that the traditions of individual peoples cannot be invoked as a pretext for disregarding the due respect for the fundamental rights proclaimed by the Universal Declaration of Human Rights." ${ }^{41}$

In essence of the "new rights," as Pierre Manent claims, is the right to be everything you want to be (le droit d'être tout ce que nous voulons être). ${ }^{42}$ The human nature as a reference point is replaced here by human will or just by dreams. This makes the "right" to be understood more and more extensively, in an essentially unconstrained way, ius omnium in omnia. It is not about the right to have some things, but to be who you want to be and to be accepted in this subjective choice, that is, surrounded by a respectable environment. In this quest says Manent - human rationality goes to the background because emotions and sensitivity predominate on the first one. A man wants to be acknowledged in accordance with how he feels or who he feels. While the "old" law prohibited entering into the public sphere issues related to, for example, sexual orientation, pushing them into the private sphere, the "new" law encourages homosexual people to escape privacy and make their sexual orientation visible. As a result,

40 Fransic, Discorso ai membri del Corpo Diplomatico accreditato presso la Santa Sede per la presentazione degli auguri per il Nuovo Anno, January 8, 2018, http://w2.vatican.va/content/ francesco/pl/speeches/2018/january/documents/papa-francesco_20180108_corpodiplomatico.html [access: August 28, 2018]; In the Polish official version 1968 is mentioned (http://w2.vatican.va/content/francesco/en/speeches/2018/january/documents/papafrancesco_20180108_corpo-diplomatico.html) [access: August 28, 2018].

41 Ibidem.

42 P. Manent, La loi naturelle et les droits de l'homme, Paris 2018, p. 86. 
it also tries to manage the feelings and judgments of the fellow citizens who react to this visibility. It wants to lead to the disappearance of feelings and negative judgments or only indifferent to homosexuality, which is objectively impossible. It is impossible to effectively manage what people think. The temptation is, therefore, to introduce a kind of "Inquisition," i.e. a ban on not only manifesting "superstitions," but also on expressing doubts or indifference towards laws that mandate public approval of homosexuality. Manent compared the attempt to juxtapose the "right to well-being" to the intention of establishing a general income without work. Living without the need to undertake any work is - as it seems - the last border, about which crossing a man dream. ${ }^{43}$

Excessive multiplication of the so-called new laws leads to inflation and banalization of the human rights language. The fact that various political groups use it to promote their own political agenda - notes Jakob Cornides - increases the risk of discrediting the very idea of human rights. ${ }^{44}$ The fact that "what was once called a 'crime' is now turned into a 'right', or even a 'fundamental right' [makes that] one cannot any more give unreserved support to all political agendas that sail under the flag of "promoting human rights." 45 Some of them are contrary to the natural law (e.g. the definition of gender in the Council of Europe Convention on Preventing and Combating Violence against Women and Domestic Violence ${ }^{46}$ ), others are promoting statutory lawlessness, and some even deserve to be called silent crimes against humanity (e.g. promotion of so-called reproductive health, aimed at limiting population growth in developing countries by facilitating access to the so-called safe abortion and sterilization).

Another challenge is the internationalization of human rights. This process is something other than the universalization of human rights, and sometimes leads to opposite results. Human rights are sometimes presented as" 'pre-positive law', which means that they

43 Cf. P. Manent, La loi naturelle et les droits de l'homme, p. 84-92.

44 A good example of this instrumentalization of the human rights language is "The Yogyakarta Principles" declaration (http://yogyakartaprinciples.org/principles-en/aboutthe-yogyakarta-principles / [access: January 20, 2018]); Cf. J. Cornides, Human Rights or Natural Law?, in: G. \& M. Kugler (eds), Exiting a Dead end Road. A GPS for Christians in Public Discourse, Vienna 2010, p. 129.

45 J. Cornides, Human Rights or Natural Law?, p. 129-130.

46 Council of Europe, Convention on preventing and combating violence against women and domestic violence, 3c, https://www.coe.int/fr/web/conventions/full-list/-/ conventions/rms/090000168008482e [access: August 28, 2018]. 
exist irrespective of a legislator will, and all positive rights should be compatible with them." ${ }^{\prime 7}$ As Cornides points out, a kind of circularity is hidden in this way of thinking. Speaking about human rights, we mean usually the rights enshrined in one of the international documents relating to human rights (e.g. the European Convention on Human Rights), which, after all, forms a part of the positive law. These conventions may even enjoy priority over other norms of law, but at the same time they have a lower rank than the natural law with which they should be compatible. As a written law, they cannot be a "pre-positive law." In addition, some activists, speaking about human rights, sometimes do not mean the rights contained in the already ratified international conventions, but those that they think should only be there (e.g. the so-called right to abortion). Cornides notes that this way of perception hides some vague belief in the existence of a natural law. How else to explain the belief that, for example, a woman has the "natural" right to kill her child in the first months of pregnancy. This unconscious faith in the "naturalness" of such "rights" could mean that the basic challenge of communication with this group of opponents might be not the question concerning the existence of natural law, but the issue of its content and mode of its reading. ${ }^{48}$

It's difficult to predict if this communication strategy could really be effective. Nevertheless, one should not forget, the authors of the United Nations Universal Declaration of Human Rights in 1948 did not want to announce just another international (inter-state) document, but a universal declaration, that is, applicable everywhere (universally), regardless of its recognition by the governments of individual states. For what has been established by agreements between states, one day may be changed by them, and what is universal will never cease to be such. ${ }^{49}$

\section{HUMAN RIGHTS AND SECULARIZATION}

The ambition of Hugo Grotius was to transform the natural law into a set of principles useful in the mutual relations between individuals, societies and states. It was about a system of rights that would remain

\footnotetext{
47 Council of Europe, Convention on preventing and combating violence..., p. 132.

48 Cf. J. Cornides, Human Rights or Natural Law?, p. 132-133.

49 Cf. V. Possenti, Diritti umani. L'età delle pretese, p. 46.
} 
valid, even if God did not exist or if he was not interested in the world: "What we have been saying would have a degree of validity even if we should concede that which cannot be conceded without the utmost wickedness, that there is no God, or that the affairs of men are of no concern to Him." 50 The proposed formula etsi Deus non daretur separated the idea of natural law from its theological foundations, transforming it into a purely theoretical reflection on the rules, which observance is a necessary condition for the survival of man as a social being. To put it shorter, it was an attempt to elaborate a completely secular theory of natural law. ${ }^{51}$

An important step on the path of emancipation from God's law authority was the French enlightenment with its Declaration of Human and Citizen Rights (1789). The authors wanted to emphasize that neither the king nor the Church are necessary for establishing a good and reasonable law. Nevertheless, in this case, the authorities were not transferred to a democratically elected legislator, who could arbitrarily determine the content of the law, but closely related to the idea of natural law (les droits naturels, inaliénables et sacrés de l'homme). The National Assembly, the content of these laws only "recognizes and declares, in the presence and under the auspices of the Supreme Being" (l'Assemblée nationale reconnaît et déclare, en présence et sous les auspices de l'Être Suprême). ${ }^{52}$ In this sense, this step did not constitute any fundamental break either in the reflection on the sources of law or in its content. Christianity never saw the source of law in religion, but in the natural law. "Unlike other great religions - said Benedict XVI in Bundestag - Christianity has never proposed a revealed law to the State and to society, that is to say a juridical order derived from revelation. Instead, it has pointed to nature and reason as the true sources of law - and to the harmony of objective and subjective reason, which naturally presupposes that both spheres are rooted in the creative reason of God." 53 In other words, Christians have greatly contributed to the secularization

50 H. Grotius, The Law of War and Peace, Prolegomena, 11, https://lonang.com/ library/reference/grotius-law-war-and-peace/gro-100/ [access: August 28, 2018].

51 Cr. J.M. Kelly, A Short History of Western Legal Theory (Polish edition: J.M. Kelly, Historia zachodniej teorii prawa, Wydawnictwo WAM, Kraków 2006), p. 250-251.

52 Cf. Déclaration des droits de l'homme et du citoyen du 26 aout 1789, Préambule, in: Direction des Journaux Officiels, Constitution. Lois organiques et ordonnances relatives aux pouvoirs publics, Edition septembre 1990, p. 221; J. Cornides, Human Rights or Natural Law?, p. 130-131.

53 Benedict XVI, Address to the Bundestag. 
of the law regulating life of the secular community, continuing the work initiated in the second century BC by the encounter of Stoic philosophers with leading teachers of the Roman Law. "Through this encounter, the juridical culture of the West was born, which was and is of key significance for the juridical culture of mankind. (...) For the development of law and for the development of humanity, it was highly significant that Christian theologians aligned themselves against the religious law associated with polytheism and on the side of philosophy, and that they acknowledged reason and nature in their interrelation as the universally valid source of law." 54 On the other hand, the very content of the Declaration of Human and Citizen Rights did not go terribly against the norms of natural law. An open conflict with the Church occurred only as a result of the adoption of the Civil Constitution of the Clergy. ${ }^{55}$

The Universal Declaration of Human Rights of the United Nations is maintained in a similar spirit, the authors referring to the moral state of indignation provoked by the crimes committed in World War II, recognized the inherent human dignity as a source of its natural rights, which are expressed in a positive form in that Declaration. Although in its preamble, even the slightest reference to God or

${ }^{54}$ Benedict XVI, Address to the Bundestag.

55 Pius VI, condemning the activities of the revolutionary authorities, refers to their attempts to subordinate to themselves the Church and to the idea of absolute freedom that they propagate, without any moral standards: "Et cependant, malgré des principes si généralement reconnus dans l'Église, l'Assemblée nationale s'est attribué la puissance spirituelle, lorsqu'elle a fait tant de nouveaux règlements contraires au dogme et à la discipline; lorsqu'elle a voulu obliger les Évêques et tous les Ecclésiastiques à s'engager par serment à l'exécution de ces décrets. Mais cette conduite n'étonnera pas ceux qui observeront que l'effet nécessaire de la constitution décrétée par l'Assemblée est d'anéantir la Religion catholique, et avec elle l'obéissance due aux rois. C'est dans cette vue qu'on établit, comme un droit de l'homme en société, cette liberté absolue, qui non-seulement assure le droit de n'être point inquiété sur ses opinions religieuses, mais qui accorde encore cette licence de penser, de dire, d'écrire et même de faire imprimer impunément en matière de religion tout ce que peut suggérer l'imagination la plus déréglée : droit monstrueux, qui paraît cependant à l'Assemblée résulter de l'égalité et de la liberté naturelles à tous les hommes. Mais que pouvait-il y avoir de plus insensé, que d'établir parmi les hommes cette égalité et cette liberté effrénée qui étouffe complètement la raison, le don le plus précieux que la nature ait fait à l'homme, et le seul qui le distingue des animaux. Dieu, après avoir créé l'homme, après l'avoir établi dans un lieu de délices, ne le menaça-t-il pas de la mort s'il mangeait du fruit de l'arbre de la science du bien et du mal ? Et par cette première défense ne mit-il pas des bornes à sa liberté ? Lorsque dans la suite sa désobéissance l'eut rendu coupable, ne lui imposa-t-il pas de nouvelles obligations par l'organe de Moïse ? et quoiqu'il eût laissé à son libre arbitre le pouvoir de se déterminer pour le bien ou pour le mal, ne l'environna-t-il pas "de préceptes et de commandements, qui pouvaient le sauver s'il voulait les accomplir?' (Ecclésiastique, XV,15-16)" (Pius VI, Bref Quod Aliquantum du 10 mars 1791 Au sujet de la constitution civile du clergé décrétée par l'Assemblée Nationale, https:// bibliothequedecombat.files.wordpress.com/2013/10/1791-pie-vi-bref-quod-aliquantum. pdf [access: January 19, 2018]). 
the Supreme Being as the source of these rights and the ultimate guarantor of human dignity has been made, nevertheless the laws contained in it are undoubtedly understood as pre-political and founded on the universal nature of man, and not only on the human contract. Since the very beginning, the Catholic Church emphasized the natural character of human rights, and at the same time pointed to the significant weakness of the Declaration, which is the lack of reference to God who is the guarantor of human dignity.

This thread can be traced on the example of Pius XII's radio-messages given on the Christmas Eve from 1941 to 1948. Already in 1941 , the pope starts to talk about the moral foundations of "the new order" which should be established once the war would be over. ${ }^{56}$ In 1942 he says: "He who would have the Star of Peace shine out and stand over society should cooperate, for his part, in giving back to the human person the dignity given to it by God from the very beginning." ${ }^{57}$ He also refers in his message to legal positivism, "which leaves the way open for a fatal divorce of law from morality." 58 Then the pope enumerates some of the basic rights of a person. ${ }^{59}$ This topic continues in 1944, when the prospect of a future declaration of human rights becomes more and more real. He especially emphasizes that God is the source and guardian of human dignity. ${ }^{60}$ In the same spirit, on December 15, 1944, he addresses a group of American congressmen, delivering to them a very clear: "At this critical moment in human history the legislators of the world's nations carry a particularly grave responsibility. The questions that they are called on to decide to have

56 Cf. Pius XII, Broadcast Message on the Christmas Eve 1942, https://w2.vatican.va/ content/pius-xii/it/speeches/1941/documents/hf_p-xii_spe_19411224_radiomessagepeace.html [access: August 28, 2018].

57 Pius XII, Broadcast Message on the Christmas Eve 1942, http://www.papapioxii.it/ english/texts / [access: August 28, 2018].

58 Ibidem.

59 Who wants peace "should favor, by every lawful means, in every sphere of life, social institutions in which a full personal responsibility is assured and guaranteed both in the early and the eternal order of things. He should uphold respect for and the practical realization of the following fundamental personal rights; the right to maintain and develop one's corporal, intellectual and moral life and especially the right to religious formation and education; the right to worship God in private and public and to carry on religious works of charity; the right to marry and to achieve the aim of married life; the right to conjugal and domestic society; the right to work, as the indispensable means towards the maintenance of family life; the right to free choice of state of life, and hence, too, of the priesthood or religious life; the right to the use of material goods; in keeping with his duties and social limitations" (Ibidem).

60 Pius XII, Broadcast Message on the Christmas Eve 1944, https://w2.vatican.va/ content/pius-xii /it/speeches / 1944/documents/hf_p-xii_spe_19441224_natale.html [access: August 28, 2018]. 
more than a passing political significance. They reach down to the roots of human society, to the inviolability of the human person, to those inalienable, God-given rights that are antecedent to the State and that no State dare infringe without jeopardizing its own existence. Foremost among those rights is the freedom to practise religion founded on faith in God and His revelation. To the legislators of today and tomorrow has been confided the noble task to ensure that those rights shall not perish, but shall be protected, defended and held in honour among all peoples." ${ }^{61}$ Pope Pius XII openly expressed his way of thinking in the letter addressed to American President Harry Truman in 1947, saying that the foundations of peace "can be secure only if they rest on bed-rock faith in the one, true God, the Creator of all men. It was He who of necessity assigned man's purpose in life; it is from Him, with consequent necessity, that man derives personal, imprescriptible rights to pursue that purpose and to be unhindered in the attainment of it. Civil society is also of divine origin and indicated by nature itself; but it is subsequent to man and meant to be a means to defend him and to help him in the legitimate exercise of his God given rights. Once the State, to the exclusion of God, makes itself the source of the rights of the human person, man is forth-with reduced to the condition of a slave, of a mere civic commodity to be exploited for the selfish aims of a group that happens to have power. The order of God is overturned; and history surely makes it clear to those who wish to read, that the inevitable result is the subversion of order between peoples, is war." ${ }^{2}$ As Daniele Menozzi remarks, after the postulate of the South American states was rejected as a result of the British intervention and it was decided that the preamble of the Declaration would not appeal to God, the reaction of the Catholic press ("L'Osservatore Romano", "La Civiltà Cattolica") to the adoption of the Declaration was negative; the Pope himself never used its name in his speech. ${ }^{63}$

We find positive statements about the Declaration only with John XXIII. In Pacem in Terris, which is a Catholic response to the UN

${ }^{61}$ Cr. Pius XII, Address to a Group of Members of the United States Congress, December 15, 1944, https://w2.vatican.va/content/pius-xii/en/speeches/1944/documents/hf_p-xii_ spe_19441215_congresso-stati-uniti.html [access: August 25, 2018].

${ }_{62}$ Pius XII, Letter to President Harry S. Truman, August 26, 1947, https://w2.vatican. va/content/pius-xii/en/letters/documents/hf_p-xii_lett_19470826_have-just.html [access: August 28, 2018].

${ }_{63}$ Cr. D. Menozzi, La Chiesa cattolica e la questione dei diritti umani, http://www. presentepassato.it/Quali_diritti/AAA_relazioni/menozzi.htm [access: August 25, 2018]. 
document of a kind, we read: "Any well-regulated and productive association of men in society demands the acceptance of one fundamental principle: that each individual man is truly a person. His is a nature, that is, endowed with intelligence and free will. As such he has rights and duties, which together flow as a direct consequence from his nature. These rights and duties are universal and inviolable, and therefore altogether inalienable."64 Human dignity has its source in God, the creator of man who shaped him in his image and likeness. It does it, on the one hand, bigger than if it was founded only on common nature, on the other hand, even more inviolable. The issue of transcendent legitimacy of human dignity was later taken by John Paul II. "Among all other earthly beings - we read in the exhortation Christifideles laici - only a man or a woman is a 'person', a conscious and free being and, precisely for this reason, the 'center and summit' of all that exists on the earth. The dignity of the person is the most precious possession of an individual. As a result, the value of one person transcends all the material world. (...) The dignity of the person is manifested in all its radiance when the person's origin and destiny are considered: created by God in his image and likeness as well as redeemed by the most precious blood of Christ, the person is called to be a 'child in the Son' and a living temple of the Spirit, destined for the eternal life of blessed communion with God. For this reason, every violation of the personal dignity of the human being cries out in vengeance to God and is an offence against the Creator of the individual." ${ }^{65}$ Even the most serious crimes against man are not able to deprive him of his inherent dignity. "But the sacredness of the human person cannot be obliterated - writes John Paul II - no matter how often it is devalued and violated because it has its unshakable foundation in God as Creator and Father. The sacredness of the person always keeps returning, again and again." ${ }^{66}$

Although the Declaration of Human Rights does not refer directly to God, it seems that it can be reasonably maintained that it was born in a context in which the natural law inscribed in the human heart and the conviction concerning common origin of people from the same

${ }^{64}$ John XXIII, Pacem in terris, 9, http://w2.vatican.va/content/john-xxiii/en/ encyclicals/documents/hf_j-xxiii_enc_11041963_pacem.html [access: August 28, 2018].

65 John Paul II, Christifideles laici, 37, http://w2.vatican.va/content/john-paul-ii/ en/apost_exhortations/documents/hf_jp-ii_exh_30121988_christifideles-laici.html [access: August 28, 2018].

${ }^{66}$ Ibidem, 5; Cf. John XXIII, Pacem in terries, 9. 
Creator, and even the creation of man "in the image and likeness of God" was commonplace. The philosophy of human rights - Georg Picht wrote - "implicitly assumes the absolute knowledge of the European metaphysics." ${ }^{\prime 27}$ The lack of invocatio Dei was generally interpreted as the desire to avoid controversy among the signatory States concerning the mode (theological or philosophical) of justification of indisputable and indivisible rights.

The secularization of Western culture changes a lot when it comes to understanding the Universal declaration of human rights, especially since it is a civilization that so far has been the most involved in promoting and protecting human dignity and inviolable human rights. Jacques Maritain in 1943 put forward the thesis that Christianity was not only indispensable for the emergence of the modern democracy along with its fundamental thesis about the inherent and inviolable dignity of the person, constituting a visible threshold between ancient and modern democracy - but also now is absolutely necessary for its survival. This is not about Christianity as a religious faith and a way leading to eternal life, but as a leaven of social and political life and as a "supplier" of hope as historical energy in the world. ${ }^{68}$ The word "God" is not understood in the religious sense (as the Being to which human piety is directed), but - as John Finnis points out - as an "Element" necessary to explain the world, to the ability to grasp the rationality and validity of the good. ${ }^{69}$ This thought is taken up by many contemporary social philosophers, such as Ernst-Wolfgang Böckenförde, Gerhard Lohfink, Leszek Kołakowski, Chantal Delsol and Robert Spaemann. "Faith in God," writes Spaemann, "gains intelligibility when we realize that without it, the claim of the inviolability of human dignity is sometimes revealed as a pleasant illusion, but often as an illusion that hinders the path towards ultimately tame society beyond freedom and dignity. If man is the supreme being only for himself, then there is no reason not to kill those whose existence does not value to anyone but to themselves. (...) Horkheimer and Adorno very well understood the logic of naturalistic relativism, saying that the only argument against

${ }^{67}$ G. Picht, Zum geistesgeschichtlichen Hintergrund der Lehre von den Menschenrechten, in: idem, Hier und jetzt, Stuttgart 1980, after: R. Spaemann, Uniwersalizm czy europocentryzm, in: K. Michalski (ed.), Rozmowy z Castel Gandolfo, Warszawa - Kraków 2010, Vol. 1, p. 490.

68 J. Maritain, Christianity and Democracy and The Rights of Man and Natural Law, San Francisco 2011, p. 21-22.

${ }^{69}$ Cf. J. Finnis, Natural Law and Natural Rights, New York 2011, p. 403-404. 
crime is ultimately the religious argument." ${ }^{" 70}$ Even if at stake would be only its "secularized" version. ${ }^{71}$

\section{HAS THE CHURCH BEEN TRAPPED IN HUMAN RIGHTS?}

Benedict XVI, speaking in the discussion on the human rights approach proposed by Marcelo Pera, writes: "It was only thanks to your book that it became clear to me how much the Pacem in Terris encyclical set a new direction for thinking. I was aware of the influence of the encyclical on Italian politics: it gave a decisive impetus to the opening of Christian Democracy to left-wing views. However, I did not realize how much it means a new premise also for the basics of this party thinking." ${ }^{22}$ Pera himself believes that the Church, recognizing that the doctrine of human rights is an expression of a better understanding of human dignity and the awareness of the rights of the person and that any discrimination in fundamental rights is "contrary to God's intent" (GS, 29), fell into a "liberal trap." ${ }^{73}$ Making the doctrine of human rights a part of the Church's Magisterium proclaimed "by virtue of the Gospel committed to her" (GS, 41) opens the question of who the interpretative power belongs to within this originally secular doctrine. It seems that

${ }^{70}$ R. Spaemann, Uniwersalizm czy europocentryzm, in: K. Michalski (ed.), Rozmowy z Castel Gandolfo, Warszawa - Kraków 2010, Vol. 1, p. 493-494. Reflecting on the need to express human rights in the form of an international declaration, Hanna Arendt writes: "The proclamation of human rights was (...) meant to be a much-needed protection in a new era where individuals were no longer secure in the estates to which they were birth or sure of their equality before God as Christians. In other words, in the new secularized and emancipated society, men were no longer sure of these social and human rights which until then had been outside the political order and guaranteed not by government and constitution, but by social, spiritual, and religious forces" (H. Arendt, Imperialism: Part two of the Origins of Totalitarianism, San Diego 1968, p. 171).

71 "The Church, having before her eyes the picture of the generation to which we belong, shares the uneasiness of so many of the people of our time. Moreover, one cannot fail to be worried by the decline of many fundamental values, which constitute an unquestionable good not only for Christian morality but simply for human morality, for moral culture: these values include respect for human life from the moment of conception, respect for marriage in its indissoluble unity, and respect for the stability of the family. Moral permissiveness strikes especially at this most sensitive sphere of life and society. Hand in hand with this go the crisis of truth in human relationships, lack of responsibility for what one says, the purely utilitarian relationship between individual and individual, the loss of a sense of the authentic common good and the ease with which this good is alienated. Finally, there is the 'desacralization' that often turns into 'dehumanization': the individual and the society for whom nothing is "sacred" suffer moral decay, in spite of appearances" (John Paul II, Dives in misericordia, 12, http://w2.vatican.va/content/john-paul-ii/en/encyclicals/ documents/hf_jp-ii_enc_30111980_dives-in-misericordia.html [access: August 05, 2019].

72 Benedict XVI (Joseph Ratzinger), Liberare la libertà. Fede e politica nel Terzo Millennio, Siena 2018, p. 8.

${ }_{73}$ Cf. M. Pera, Diritti umani e cristianesimo. La Chiesa alla prova della modernità, p. $37-44$. 
the Church should have her own interpretation of human rights and, consequently, try to impose this interpretation on secular institutions. An alternative solution would be to recognize that the power of interpretation is vested in secular institutions, and that the Church, under their influence, should make a permanent reinterpretation of her Magisterium. Put simply: since the doctrine of human rights is part of the Church's Magisterium and at the same time is a kind of secular religion in the world of politics, the question is whether the Church's teaching office should decide on the proper interpretation of the creed of this "secular religion" or vice versa: "secular magisterium" has the right to decide on the content of the Magisterium of the Church? So, should secular magisterium in the form of opinions and judgments of, for example, the UN Human Rights Commission, the European Court of Human Rights or the Supreme Court of the United States, be superior to the Church's teaching office or vice versa? Who should, therefore, have interpretative power to decide if the right to abortion or euthanasia is a human right or not? Who should have the power to decide whether the right to marry and found a family also apply to people of the same sex? Recognition of the superiority of the Church authority in this area could be seen as an attempt to build a modern confessional state. Recognition of the supremacy of the secular authority would also give it authority over the Church's Magisterium, probably imposing on the Church the obligation to incorporate to her doctrine (and to proclaim "by virtue of the Gospel") also of the so-called new human rights. The third conceivable solution would be to recognize that human rights in both approaches do not have too many common points, because one concept is secular and the other religious. So, they use two different languages.

Pera recalls that the contemporary doctrine of human rights is built on the foundation of the moral philosophy of Immanuel Kant. This means that recognition of the priority of man's duties to his rights is common to both the Christian and Kantian interpretations. However, the rationale for the inviolable dignity of the human person in both traditions is fundamentally different. The practical imperative around which the Kantian theory of human rights is built reads as follows: "Act as to treat humanity, whether in thine own person or in that of any other, in every case as an end withal, never as means only." ${ }^{74}$

${ }^{74}$ I. Kant, Fundamental Principles of the Metaphysic of Morals, Apple Books, https:// books.apple.com/pl/book/fundamental-principles-of-the-metaphysic-of-morals/id501616 036?l=pl, p. 96-97. 
The declaration about the dignity of the human person, which can never be treated only instrumentally - comments Pera - is preceded by the expression "Now I say" (nun sage ich), ${ }^{75}$ which can be regarded as a kind of profession of religious faith in the sanctity of a person. ${ }^{76}$ Kant's stance can be reduced to three main principles:

- the moral law is of a rational nature;

- the consequence of the recognition by reason of the moral law is a categorical imperative, requiring respect for human dignity, as a universal and absolute duty;

- the duties resulting from the respect of the person correspond with the rights of the person, while the only original right of every person is the right to freedom. ${ }^{77}$

The human person in the philosophy of Kant has its inviolable value regardless of the Creator. The duties that Kant speaks of are established by autonomous reason and therefore without looking at God. Although the content of morality based on categorical imperative he considers as identical with the love of the neighbor that Jesus commended, he also stresses that Jesus himself cannot be a moral authority for a man, unless his own reason will order him to grant Him such authority. For man to recognize his duties and rights, God is not necessary. The final criterion of morality is individual reason, and not any external authority, even if it was Jesus Christ. ${ }^{78}$

Thus, we have a Kantian morality built around the principle of autonomy and Christian morality built around the principle of dependence on God. From the above it does not follow that the idea of God does not appear at all in the area of Kantian morality. However, God is not a condition for the individual to understand his duties and rights, but a condition for leaving the "ethical state of nature" in order to establish an ethical community. The ethical state of nature is understood here in the image of Thomas Hobbes's state of nature: "Just as the juridical state of nature is one of war of every man against every other, so too is the ethical state of nature one in which the good principle, which resides in each man, is continually attacked by the evil which is found in him and also in everyone else."79 The concept

${ }^{75}$ I. Kant, Fundamental Principles of the Metaphysic of Morals, p. 94.

${ }^{76}$ Cf. M. Pera, Diritti umani e cristianesimo. La Chiesa alla prova della modernità, p. 96.

77 Cf. ibidem, p. 97.

${ }^{78}$ Cf. A. MacIntyre, A Short History of Ethics: A History of Moral Philosophy from the Homeric Age to the Twentieth Century, London 2000, p. 147.

79 I. Kant, Religion within the Limits of Reason Alone, III, 2, http://staffweb.hkbu.edu. hk/ppp/rbbr/toc.html, p. 88 [access: August 05, 2019]. 
of God as the "moral ruler of the world" is a necessary condition for the emergence of an ethical community, because it can be thought of only as a people under divine commands, i.e., as a people of God, and indeed under laws of virtue." 80 It's all about a "practical and necessary religious idea" which "can be made comprehensible to each man through his reason." 81

Because pure virtue - notes Otfried Höffe - is something internal, also a community organized solely according to the law of virtue cannot be given to a concrete experience. It must be an invisible community. Even if it is called the People of God or the Kingdom of God, it has only a loose relationship - through the shared confession of the Creed - with the visible Church. "Here a kingdom of God is represented not according to a particular covenant (i.e., not Messianic) but moral (knowable through unassisted reason." 82 The true moral service to God is invisible. It consists in observing all true duties as divine commandments, and not on actions performed exclusively for God. ${ }^{83}$ Kant, like Jean Jacques Rousseau, the moral religion of virtuous life opposes to all historical religions in which the faithful make a moral effort to please God. "Any religiously opportunistic intention, deviating from moral intent and seeking to please God and to gain His grace - as Höffe comments Kant's idea - denies the principle of autonomy, and therefore it should be rejected for moral reasons." 84

Pera draws two important conclusions from the above. First, in Christianity moral duties are not the result of human reflection but are commanded by God in the form of the commandments contained in the Decalogue. The dignity of the human person has its justification in creating it in the image and likeness of God, and not just in its rational nature. This means that the justification of dignity based on natural law is correct, but it does not go far enough, which entails certain practical consequences. Secondly, and more importantly, in a world where morality can be justified on a completely secular way, the God of Christians is no longer needed. God, who previously was an indispensable justification for the dignity of the human person,

${ }^{80}$ I. Kant, Religion within the Limits of Reason Alone, III, 3, p. 91.

81 Ibidem, General Observation, p. 136.

82 Ibidem, footnote, p. 127.

83 Cf. ibidem, General Remark, 5.1, https://kantwesley.com/Kant/RationalReligion. pdf, p. 193 [access: August 05, 2019].

${ }_{84}$ O. Höffe, Immanuel Kant, (Polish edition: Wydawnictwo Naukowe PWN, Warszawa 1994, p. 259). 
becomes superfluous in the universe, in which respect for the human person is guaranteed by the culture of human rights. Admittedly, it is still socially necessary, but only temporally as the functional argument for the ethical community. Thirdly, according to Pera, the doctrine of human rights functions in the Western society in a way of secular religion. This is, paradoxically, due to the deep-rooted conviction that social cohesion cannot be guaranteed purely in secular terms. It means, however, that the secular human rights culture, being in fact crypto-religious, is competitive against Christianity.

We mentioned the multiplication of human rights. Rights generate further rights that - entering into conflict with previously recognized somehow "consume" previous rights. Multiplication and banalization of rights - it seems - is a consequence of the adoption of a categorical imperative as the only source of moral law. Meanwhile, as pointed out, for example, by Alasdair MacIntyre, with the help of this tool, you can prove everything you want. "In practice the test of categorical imperative imposes restrictions only on those insufficiently equipped with ingenuity. (...) Because the Kantian notion of duty is formal that it can be given almost any content, it becomes available to provide a sanction and a motive to for the specific duties which any particular social and moral tradition may propose." ${ }^{85}$ There is therefore no point in arguing about whether something is a human right or not, because obtaining a positive answer depends only on the intellectual ability of the lawyer. Thus, there are also no limits in lawmaking that would protect the inviolable human dignity. At the same time, laws that were supposed to protect the individual from state interference as pre-political are now being appropriated by political instances, becoming only a specific kind of positive law. ${ }^{86}$ "The multiplication of rights writes Benedict XVI - ultimately leads to the destruction of the idea of the right and necessarily leads to the nihilistic 'right' of man to deny himself: abortion, suicide, the production of man as he would be an object they become human rights even if they deny human dignity at the same time." $" 87$

The problem - according to Pera - is that the proliferation of human rights takes place not only in the documents of international

\footnotetext{
${ }^{85}$ Cf. A. MacIntyre, A Short History of Ethics: A History of Moral Philosophy from the Homeric Age to the Twentieth Century, p. 149.

${ }^{86}$ Cf. M. Pera, Diritti umani e cristianesimo. La Chiesa alla prova della modernità, p. 71.

87 Benedict XVI (Joseph Ratzinger), Liberare la libertà. Fede e politica nel Terzo Millennio, p. 14.
} 
law, but also in Church documents. ${ }^{88}$ With each new Catholic social doctrine document, the list of rights is prolonged. Meanwhile - as he claims - between the liberal concept of human rights, coming from the conviction that the autonomy of the individual means unlimited freedom, also in the field of establishing a moral law, and the Christian vision of man as subject to God and obliged to use freedom in the framework of God's commandments, takes place not only the difference, but contradiction clearly expressed by the former Church teaching. It is of course possible to overcome the line of historical division, but only due to a radical reinterpretation of the Catholic doctrine. This raises the question of the limits of acceptable adaptation of the Church's teaching to the doctrines and political practice of the world, and of the convincing criterion to decide which of the "new" human rights should become part of the Catholic doctrine proclaimed with "by virtue of the Gospel" and which should be rejected by the Church. ${ }^{89}$

Still there remains the question of the application of human rights in the internal practice of the Catholic Church. Do priests also have the right to marry and form a family? Do women have the right to be employed in the Church without any discrimination based on sex, and therefore also to receive ordination? Should canon law grant the faithful the right to divorce, not to mention the "right" to abortion or artificial procreation? Should the Church grant theologians the right to publicly oppose the statements of the Magisterium? ${ }^{90}$ Of course, the Church could, by way of exemption, refuse certain rights to the faithful, but - as demonstrated by the political practice in the European Union such a refusal in a shorter perspective contributes to creating a negative image of the Church as an institution which - on an exceptional basis - may violate human rights for a time, but in the long term perspective this kind of practice seems completely untenable.

${ }^{88}$ Cf. M. Pera, Diritti umani e cristianesimo. La Chiesa alla prova della modernità, p. 51-53.

89 Cf. ibidem, p. 144-145.

90 In the Instruction of the Congregation for the Doctrine of the Faith, we find a clearly articulated opposite thought: "One cannot then appeal to these rights of man in order to oppose the interventions of the Magisterium. Such behavior fails to recognize the nature and mission of the Church which has received from the Lord the task to proclaim the truth of salvation to all men. She fulfills this task by walking in Christ's footsteps, knowing that "truth can impose itself on the mind only by virtue of its own truth, which wins over the mind with both gentleness and power" (Congregation for the Doctrine of the Faith, Donum veritatis. Instruction on the Ecclesial Vocation of the Theologian, 36, http:/ /www.vatican.va/ roman_curia/congregations/cfaith/documents/rc_con_cfaith_doc_19900524_theologianvocation_en.html) [access: August 05, 2019]. 
"Thus, [Marcelo Pera] in his book convincingly emerges that the idea of human rights separated from the idea of God ultimately leads not only to the marginalization of Christianity, but eventually to its denial. This (...) is of great significance in the face of the current spiritual development of the West which always denies its Christian foundations and turns against them." ${ }^{\prime 1}$ In the face of the above challenges, Benedict XVI encourages theologians to "a new reflection" on theology of human rights. ${ }^{92}$ It is difficult to imagine, even for purely pragmatic reasons, that the Church may suddenly withdraw from the declarations made in Gaudium et spes or in Pacem in terris. It is also difficult to imagine disregarding the opinion of Benedict XVI that the position adopted in Pacem in terris pushes the Church to the leftist political positions and pushes God beyond the area of human interest. Hence the urgent question: is there any theologically correct way to justify the need for the Church to proclaim human rights with the "by virtue of the Gospel?" 93

${ }_{91}$ Benedict XVI (Joseph Ratzinger), Liberare la libertà. Fede e politica nel Terzo Millennio, p. 14 .

92 "Many people today would claim that they owe nothing to anyone, except to themselves. They are concerned only with their rights, and they often have great difficulty in taking responsibility for their own and other people's integral development. Hence it is important to call for a renewed reflection on how rights presuppose duties, if they are not to become mere licence. Nowadays we are witnessing a grave inconsistency. On the one hand, appeals are made to alleged rights, arbitrary and non-essential in nature, accompanied by the demand that they be recognized and promoted by public structures, while, on the other hand, elementary and basic rights remain unacknowledged and are violated in much of the world. A link has often been noted between claims to a "right to excess," and even to transgression and vice, within affluent societies, and the lack of food, drinkable water, basic instruction and elementary health care in areas of the underdeveloped world and on the outskirts of large metropolitan centres. The link consists in this: individual rights, when detached from a framework of duties which grants them their full meaning, can run wild, leading to an escalation of demands which is effectively unlimited and indiscriminate. An overemphasis on rights leads to a disregard for duties. Duties set a limit on rights because they point to the anthropological and ethical framework of which rights are a part, in this way ensuring that they do not become licence. Duties thereby reinforce rights and call for their defence and promotion as a task to be undertaken in the service of the common good. Otherwise, if the only basis of human rights is to be found in the deliberations of an assembly of citizens, those rights can be changed at any time, and so the duty to respect and pursue them fades from the common consciousness. Governments and international bodies can then lose sight of the objectivity and "inviolability" of rights. When this happens, the authentic development of peoples is endangered. Such a way of thinking and acting compromises the authority of international bodies, especially in the eyes of those countries most in need of development. (...) The sharing of reciprocal duties is a more powerful incentive to action than the mere assertion of rights" (Benedict XVI, Caritas in veritate, 43, http://w2.vatican.va/content/benedict-xvi/en/encyclicals/documents/ hf_ben-xvi_enc_20090629_caritas-in-veritate.html\#_edn 106) [access: August 05, 2019].

${ }_{93} C f$. M. Pera, Diritti umani e cristianesimo. La Chiesa alla prova della modernità, p. 98 and 143 


\section{FROM THE OLD TYPE HYPOCRISY OF TO THE NEW TYPE HYPOCRISY}

Secularization, it seems, exposes the doctrine of human rights to new dangers, completely different from those of the Cold War time. John Finnis wrote in 1980: "Whatever may be commonly professed in the modern world, no contemporary government or elite manifests through any belief in absolute human rights. For every government that has the physical capacity to make its threats credible says this to its potential enemies: 'If you attack us and threaten to defeat us, we will kill all the hostages we hold; that is to say, we will incinerate or dismember as many of your old men and women and children, and poison as many of your mothers and their unborn offspring, as it takes to persuade you to desist; we do not regard as decisive the fact that they are themselves not threat to us; nor do we propose to destroy them merely incidentally, as an unsought-after side-effect of efforts to stop your armed forces in their attack on us; no, we will destroy your non-combatants precisely because you value them, and in order to persuade you to desist'. (...) Those who say this and have been preparing elaborately for years to act upon their threat (and most of them acted upon it massively, between 1943 and 1945, to say no more), cannot be said to accept that anyone has, in virtue of his or her humanity any absolute right" - Finnis concludes. ${ }^{94}$ The Cold War threat was associated with a visible discrepancy between the professed or declared theory about the inviolability of human dignity and the actions actually undertaken. Today, the doctrine of human rights is in danger not only in fact, but also on the theoretical field. "Because the anthropology on which the traditional philosophy of human rights is based, even in its European homeland has been irreversibly destroyed - writes Georg Picht - the utopia of the global human rights system can be described as an empty illusion." 95 It is difficult to say whether the situation is so serious, but it is certainly very serious, because the way of interpreting the doctrine of human rights in the secularized world of the West is becoming more and more frivolous. In this context, the statement that "human rights constitute a socially effective and adjust to our

\footnotetext{
94 J. Finnis, Natural Law and Natural Rights, p. 224.

95 G. Picht, Zum geistesgeschichtlichen Hintergrund der Lehre von den Menschenrechten, in: idem, Hier und jetzt, Stuttgart 1980, p. 490.
} 
time form of the doctrine of natural law"96 does not seem so obvious anymore.

This dramatic state of affairs, according to Benedict XVI, is connected with the dissemination of a positivist worldview, which by announcing that ethos and religion do not belong to the realm of reason in the strict sense - sent them back to the private sphere, recognizing positivist reason as the only legitimate source of culture. Although "the positivist world view in general, is a most important dimension of human knowledge and capacity that we may in no way dispense with - says the pope - But in and of itself it is not a sufficient culture corresponding to the full breadth of the human condition. Where positivist reason considers itself the only sufficient culture and banishes all other cultural realities to the status of subcultures, it diminishes man, indeed it threatens his humanity. (...) In its self-proclaimed exclusivity, the positivist reason which recognizes nothing beyond mere functionality resembles a concrete bunker with no windows, in which we ourselves provide lighting and atmospheric conditions, being no longer willing to obtain either from God's wide world." 97 This kind of approach to the culture makes Europe defenseless vis-à-vis other world cultures. It puts Europe in a state of culturelessness, which provokes the activation of radical and extremist trends on the Old Continent, emerging in the vacuum. However, the positivist reason - notes the pope - is not self-sufficient. In order to preserve the remnants of rationality, so that its postulates of transforming the world would not deny the entire humanistic achievements of civilization, it still has to draw from "God's raw materials," only that it does it secretly, not disclosing all the sources from which it has derived its "secular" products. It is also a kind of hypocrisy. To get rid of it, "the windows must be flung open again, we must see the wide world, the sky and the earth once more and learn to make proper use of all this." 98

$$
* * *
$$

Experienced relativization of human rights means that the criminality of totalitarian systems also disappears from our outlook,

96 B. Sutor, Kleine politische Ethik (Polish edition: Etyka polityczna, „Kontrast” Wydawnictwo Fundacji ATK, Warszawa 1994, p. 203).

97 Benedict XVI, Address to the Bundestag.

98 Ibidem. 
since, from this point of view, they violate only international law that was solely a convention binding at the time. Therefore, there were no significant reasons not to kill Jews or representatives of other minorities, apart from a few historically conditioned prejudices and a specific aesthetic sensitivity. Today, this way of thinking is applied to children conceived and unborn or people submitted to euthanasia. Fact that one can think this way displays the drama of our current situation. And yet, these kinds of thoughts are not only billowing in our heads but are also loudly expressed in the salons. In order not to end pessimistically, let us return once again to Radbruch's thought: "When laws constitute an open violation of the will to bring justice, granting human rights to some people and denying them the rest, because that is someone's whim, no authority is given to these regulations and no one, to the smallest extend, is obliged by them. Lawyers also have to find courage and deny these regulations the character of law." ${ }^{99}$ Such courageous people have always been, though few, and there is no reason to believe that they will ever be missing.

\section{BIBLIOGRAPHY}

"The Yogyakarta Principles" declaration (http://yogyakartaprinciples. org/principles-en/about-the-yogyakarta-principles / [access: January 20, 2018].

Arendt H., Imperialism: Part two of the Origins of Totalitarianism, Harcourt Brace \& Company, San Diego 1968.

Benedict XVI (Joseph Ratzinger), Liberare la libertà. Fede e politica nel Terzo Millennio, Edizioni Cantagalli, Siena 2018.

Benedict XVI, Address to the Bundestag, September 22, 2011, http:// w2.vatican.va/content/benedict-xvi/en/speeches/2011/september/ documents/hf_ben-xvi_spe_20110922_reichstag-berlin.html [access: August 28, 2018].

Benedict XVI, Address to the General Assembly of the United Nations Organization, April 18, 2008, http://w2.vatican.va/content/benedictxvi/en/speeches/2008/april/documents/hf_ben-xvi_spe_20080418_ un-visit.html [access: August 28, 2018].

Benedict XVI, Caritas in veritate, 43, http://w2.vatican.va/content/ benedict-xvi/en/encyclicals/documents/hf_ben-xvi_enc_20090629_ caritas-in-veritate.html\#_edn106) [access: August 05, 2019].

Cairo Declaration on Human Rights in Islam, Preamble, http://www. bahaistudies.net/neurelitism/library/Cairo_Declaration_on_Human_ Rights_in_Islam.pdf [access: August 28, 2018].

${ }_{99}$ G. Radbruch, Philosophy of Law, p. 242. 
Chan B.S.B., Are International Human Rights Universal? East-West Philosophical Debates on Human Rights to Liberty and Health, in: L. Di Donato, E. Grimi (eds), Metaphysics of Human Rights. 1948-2018. On the Occasion of the 70th Anniversary of the UDHR, Vernon Press, Malaga 2018.

Congregation for the Doctrine of the Faith, Donum veritatis. Instruction on the Ecclesial Vocation of the Theologian, 36, http://www.vatican. va/roman_curia/congregations / cfaith/documents/rc_con_cfaith_ doc_19900524_theologian-vocation_en.html [access: August 05, 2019].

Convention on the Rights of the Child, 7, https://www.ohchr.org/en/ professionalinterest/pages/crc.aspx [access: August 28, 2018].

Cornides J., Human Rights or Natural Law?, in: G. \& M. Kugler (eds) Exiting a Dead end Road. A GPS for Christians in Public Discourse, Kairos Publications, Vienna 2010, p. 129.

Council of Europe Convention on preventing and combating violence against women and domestic violence, 3c, https://www.coe.int/fr/ web/conventions / full-list/-/conventions / rms / $090000168008482 \mathrm{e}$ [access: August 28, 2018].

Déclaration des droits de l'homme et du citoyen du 26 aout 1789, Préambule, in: Direction des Journaux Officiels, Constitution. Lois organiques et ordonnances relatives aux pouvoirs publics, Edition septembre.

Final Declaration of the Regional Meeting for Asia of the World Conference on Human Rights, April 02, 1993, n. 8, faculty.washington.edu/.../ pols469/Bangkok_Declaration.doc [access: July 08, 2019].

Finnis J., Natural Law and Natural Rights, Oxford University Press, New York 2011.

Fransic, Discorso ai membri del Corpo Diplomatico accreditato presso la Santa Sede per la presentazione degli auguri per il Nuovo Anno, January 8, 2018, http://w2.vatican.va/content/francesco/pl/speeches/2018/january/ documents/papa-francesco_20180108_corpo-diplomatico.html [access: August 28, 2018]; In the Polish official version 1968 is mentioned (http://w2.vatican.va/content/francesco/en/speeches/2018/january/ documents/papa-francesco_20180108_corpo-diplomatico.html [access: August 28., 2018]).

Grotius H., The Law of War and Peace, Prolegomena, 11, https: / /lonang. com/library/reference/grotius-law-war-and-peace/gro-100/ [access: August 28, 2018].

Höffe O., Immanuel Kant, (Polish edition: Wydawnictwo Naukowe PWN, Warszawa 1994).

Hume D., A Treatise of Human Nature, I.I.1, iBooks, https://itunes.apple. $\mathrm{com} / \mathrm{pl} /$ book/a-treatise-of-human-nature/id506006779?1=pl\&mt=11. 
John Paul II, Christifideles laici, 37, http://w2.vatican.va/content/johnpaul-ii/en/apost_exhortations/documents/hf_jp-ii_exh_30121988_ christifideles-laici.html [access: August 28, 2018].

John Paul II, Dives in misericordia, 12, http://w2.vatican.va/content/ john-paul-ii/en/encyclicals/documents/hf_jp-ii_enc_30111980_ dives-in-misericordia.html [access: August 05, 2019].

John XXIII, Pacem in terris, 9, http://w2.vatican.va/content/john-xxiii/ en/encyclicals/documents/hf_j-xxiii_enc_11041963_pacem.html [access: August 28, 2018].

Kant I., Fundamental Principles of the Metaphysic of Morals, Apple Books, https:/ / books.apple.com/pl/book/fundamental-principles-of-themetaphysic-of-morals/id501616036?1=pl.

Kant I., Religion within the Limits of Reason Alone, III, 2, http:/ /staffweb. hkbu.edu.hk/ppp/rbbr/toc.html, p. 88 [access: August 05, 2019].

Kelly J.M., A Short History of Western Legal Theory (Polish edition: J.M. Kelly, Historia zachodniej teorii prawa, Wydawnictwo WAM, Kraków 2006).

Kelsen H., Pure Theory of Law, University of California Press, Berkeley 1967. MacIntyre A., A Short History of Ethics: A History of Moral Philosophy from the Homeric Age to the Twentieth Century, Routledge, London 2000.

MacIntyre A., After Virtue. A Study in Moral Theory (Polish edition: A. MacIntyre, Dziedzictwo cnoty. Studium $z$ teorii moralności, Wydawnictwo Naukowe PWN, Warszawa 1996).

Manent P., La loi naturelle et les droits de l'homme, Presses Universitaires de France, Paris 2018.

Maritain J., Christianity and Democracy and The Rights of Man and Natural Law, Ignatius Press, San Francisco 2011.

Menozzi D., La Chiesa cattolica e la questione dei diritti umani, http:// www.presentepassato.it/Quali_diritti/AAA_relazioni/menozzi.htm [access: August 25, 2018].

Origen, Contra Celsum, I,1, http://www.documentacatholicaomnia.eu/ 03d/0185-0254,_Origenes,_Contra_Celsus,_EN.pdf [access: August 28, 2018].

Paul VI, Populorum progressio, 42, http://w2.vatican.va/content/paul$\mathrm{vi} /$ en/encyclicals/documents/hf_p-vi_enc_26031967_populorum. html [access: August 28, 2018].

Pera M., Diritti umani e cristianesimo. La Chiesa alla prova della modernità, Marsilio Nodi, Venezia 2015.

Picht G., Zum geistesgeschichtlichen Hintergrund der Lehre von den Menschenrechten, in: idem, Hier und jetzt, Stuttgart 1980.

Pius VI, Bref Quod Aliquantum du 10 mars 1791 Au sujet de la constitution civile du clergé décrétée par l'Assemblée Nationale, https:/ / bibliothequedecombat.files.wordpress.com/2013/10/1791pie-vi-bref-quod-aliquantum.pdf [access: January 19, 2018]. 
Pius XII, Address to a Group of Members of the United States Congress, December 15, 1944, https://w2.vatican.va/content/pius-xii/en/ speeches / 1944/documents/hf_p-xii_spe_19441215_congresso-statiuniti.html [access: August 25, 2018].

Pius XII, Broadcast Message on the Christmas Eve 1942, http://www. papapioxii.it/english/texts/ [access: August 28, 2018].

Pius XII, Broadcast Message on the Christmas Eve 1942, https:// w2.vatican.va/content/pius-xii/it/speeches/1941/documents/hf_pxii_spe_19411224_radiomessage-peace.html [access: August 28, 2018].

Pius XII, Broadcast Message on the Christmas Eve 1944, https:// w2.vatican.va/content/pius-xii/it/speeches/1944/documents/hf_pxii_spe_19441224_natale.html [access: August 28, 2018].

Pius XII, Letter to President Harry S. Truman, August 26, 1947, https:// w2.vatican.va/content/pius-xii/en/letters/documents/hf_p-xii_ lett_19470826_have-just.html [access: August 28, 2018].

Possenti V., Diritti umani. L'età delle pretese, Rubbettino, Soveria Mannelli 2017.

Radbruch G., Philosophy of Law (Polish edition: Filozofia prawa, Wydawnictwo Naukowe PWN, Warszawa 2011).

Sarah R., Diat N., Le soir approche et déjà le jour baisse, Fayard, Paris 2019.

Spaemann R., Uniwersalizm czy europocentryzm, in: K. Michalski (ed.), Rozmowy z Castel Gandolfo, Warszawa - Kraków 2010, Vol. 1.

Sutor B., Kleine politische Ethik (Polish edition: Etyka polityczna, „Kontrast” Wydawnictwo Fundacji ATK, Warszawa 1994).

Talmon J.L., The Origins of Totalitarian Democracy, Secker \& Warburg, London 1952.

Universal Islamic Declaration of Human Rights, Foreword, http://www. alhewar.com/ISLAMDECL.html [access: August 28, 2018]. 